\title{
Genetic variation in the clonal bryophyte Hylocomium splendens at hierarchical geographical scales in Scandinavia
}

\author{
NILS CRONBERG* $\uparrow$, ULF MOLAU $\ddagger$ \& MATS SONESSON§ \\ $\nmid$ Department of Systematic Botany, University of Lund, Ö. Vallgatan 18-20, S-223 61 Lund, łDepartment of \\ Systematic Botany, University of Göteborg, Carl Skottsbergs Gata 22, S-413 19 Göteborg and §Abisko Scientific \\ Research Station, The Royal Swedish Academy of Sciences, S-981 07 Abisko, Sweden
}

\begin{abstract}
The widespread bryophyte Hylocomium splendens was sampled in a hierarchical fashion from populations representing four Scandinavian vegetation zones. Allozyme electrophoresis revealed variation at 11 out of 13 screened loci, allowing accurate identification of genotypes. From a total sample of 298 shoots 79 genotypes could be detected, giving the proportion of distinguishable genotypes $(P D)$ of 0.265 . The total allelic diversity $\left(H_{\mathrm{T}}\right)$ based on polymorphic loci was 0.274 . The relative differentiation among populations was low $\left(G_{\mathrm{ST}}=0.073\right)$, indicating a high level of gene flow. Differences in population structuring occurred between a subarcticalpine site vs. three lowland sites. The subarctic-alpine population had one widespread clone, which appeared to be propagated by dispersal of vegetative fragments. That population also comprised many rare genotypes, often occurring together within $10 \times 10 \mathrm{~cm}$ patches. The lowland populations had genotypes that were locally common and often dominant within the patches. When identical genotypes were observed in multiple patches within these populations, it was usually statistically highly probable that they had arisen by independent sexual recombinations.
\end{abstract}

Keywords: allozyme, Bryophyta, clonal plant, genetic diversity, hierarchical variation, Hylocomium splendens.

\section{Introduction}

It is often assumed that a shift from sexual to vegetative reproduction decreases genetic diversity, because of reduced genetic recombination (Mischler, 1988). Empirical data obtained mainly from allozyme studies show that clonal plants, in general, are as variable as other plants despite low levels of observed sexual recombination (Ellstrand \& Roose, 1987; Widén et al., 1994). At their northern limits of distribution, plants often rely largely upon vegetative reproduction for maintenance (Longton \& Schuster, 1983; Hermanutz et al., 1989). To date, however, few studies of genetic population structure in arctic and subarctic-alpine clonal plants have been carried out (see Molau, 1993, for a review).

In contrast to other land plants, the haploid generation, rather than the diploid, forms the dominant phase of the life cycle of bryophytes. This

\footnotetext{
*Correspondence. E-mail: nils.cronberg@sysbot.lu.se
}

implies several important genetic differences relative to vascular plants. For example, deleterious mutations are always expressed and directly exposed to selection, heterozygotic superiority can only exist in the short-lived sporophytic phase and gametes are produced by mitosis and therefore in principle genetically identical (Wyatt, 1982). In recent years the view that bryophytes have a low 'evolutionary potential', caused by haploidy and predominant asexual reproduction, has been questioned by authors who have detected high levels of variation as measured by allozyme electrophoresis (review: Stoneburner et al., 1992).

Hylocomium splendens (Hedw.) B.S.G. belongs to the perennial stayer life form category of bryophytes (During, 1992), characterized by long clonal life spans, predominance of asexual reproduction by vegetative growth, rarity of sexual reproduction and low spore production. At high altitudes, $H$. splendens is rarely fertile according to the records (Mårtensson, 1956; Callaghan et al., 1978), but at lower eleva- 
tions spore capsules are occasionally encountered (N. Cronberg, personal observation). There are few observations of sexual recruitment (Tamm, 1953) and germination tests of soil samples show that a spore bank is lacking (Jonsson, 1993a). The rapid recolonization of disturbed patches is presumed to be brought about by vegetative propagation, viz., dispersal of detached fragments (Jonsson, 1993b), which readily regenerate new shoots (Myrmael, 1993). Asexual reproduction takes place also by branching of the main shoots (Økland, 1995). After some years of growth the older parts of the stem decompose and the connection between ramets is lost. Colonies of $H$. splendens in boreal forest are persistent in comparison with other bryophytes (Økland, 1994), but demographic data show that annually 7 per cent of segment chains are lost and 1.5 per cent are re-established in new sites ( $\varnothing$ kland, 1995).

This study aims to compare the genetic population structure and clonal diversity of the widely distributed $H$. splendens over vegetation and climate zones. The sampling procedure was designed to focus on the hierarchical spatial differentiation of populations.

\section{Materials and methods}

\section{The plant}

Hylocomium splendens is a common bryophyte on the floor of boreal forests, where it forms loose and sometimes patchy carpets. It has a wide ecological amplitude (Tamm, 1953; Callaghan et al., 1978; Sonesson et al., 1992; Økland, 1994) and extends from the temperate zone to the High Arctic of the N. Hemisphere (Schofield, 1985). Small, unipinnate and densely growing plants with small, ovate stem leaves, often with an apiculus, are found in dry, exposed subarctic to arctic heaths. Taxonomically these forms have sometimes been treated as a separate species, e.g. Hylocomium alaskanum (Lesq. \& James) Aust. (see Persson \& Viereck, 1983, for a recent review).

\section{Sampling procedure and sites}

We collected from each population three 'subpopulations', $250-3000 \mathrm{~m}$ apart. A subpopulation consisted of five 'patches', one located at each of the corners, and at the centre of a $10 \times 10 \mathrm{~m}$ quadrat. At each patch, five 'shoots' were collected, one from each of the four corners, and from the centre of a $10 \times 10 \mathrm{~cm}$ quadrat. The complete subpopulation sample thus consisted of 25 shoots. In the first year (1991) one such sample was collected from each of two locations: at Stordalen (STO) and at Latnjajaure (LAT), near Abisko Scientific Research Station in N. Sweden (Table 1, Fig. 1). In the next summer more material was gathered from these sites and two lowland populations representing the $\mathrm{N}$. and $\mathrm{S}$. boreal zones of Scandinavia (LÅN and ANE). The plants from LAT showed morphological traits typical of 'Hylocomium alaskanum'.

\section{Electrophoretic procedures}

The top $1-2 \mathrm{~cm}$ of shoots were homogenized in 30-40 $\mu \mathrm{L}$ extraction buffer (stock solution $\mathrm{pH}$ 7.0: $0.1 \mathrm{M}$ Tris; $0.033 \mathrm{M}$ citric acid; 2 per cent triton $\mathrm{X}-100$; just before extraction was added: 2 per cent PVP, $40000 \mathrm{M}$ quality; 0.2 per cent di-mercaptoethanol; 0.1 per cent BSA; 5 per cent sucrose) together with a small amount of fine sand. A limited number of spore capsules were extracted to test if interpretable bands could be detected from the diploid sporophytic phase of the life cycle. Extracts were loaded onto $6 \mathrm{~mm} \times 3 \mathrm{~mm}$ wicks of Whatman filter paper no. 3. The material was kept on ice during extraction. Paper wicks were stored at $-80^{\circ} \mathrm{C}$ until use.

The gel-electrode buffer systems used were standard LiOH buffer (Soltis et al., 1983; no. 7), histidine buffer (Soltis et al., 1983; no. 1, with 4 per cent sucrose added), and morpholine-citrate (Wendel \& Weeden, 1989; no. 2). Electrophoresis was performed on $6 \mathrm{~mm}$ thick horizontal starch gels with a starch concentration of 10.5 per cent. After separation, enzymes were stained using standard colorimetric methods (Wendel \& Weeden, 1989). The LiOH buffer resolved aspartate aminotransferase (AAT, EC 2.6.1.1), glucose-6-phosphate isomerase (GPI, EC 5.3.1.9), and triose-phosphate isomerase (TPI, EC 5.3.1.1); the histidine buffer resolved isocitrate dehydrogenase (IDH, EC 1.1.1.42) and phosphoglucomutase (PGM, EC 5.4.2.2); and the morpholine-citrate buffer resolved aconitase (ACO, EC 4.2.1.3), fructose-bisphosphate aldolase (FBA, EC 4.1.2.13), malate dehydrogenase (MDH, EC 1.1.1.37) and 6-phosphogluconate dehydrogenase (PGD, EC 1.1.1.43). About a quarter of the material was later re-extracted and reanalysed in order to check the reliability of the enzyme bands.

Enzyme loci were numbered in relation to their migration distance, beginning at the cathodal end of the gel, with alleles ordered alphabetically, the $a$-allele of each locus having the shortest migration distance. 


\section{Data analysis}

Gene frequencies were calculated at two levels of organization: (1) ramet level, by considering each shoot as a separate entity in calculations, and (2) genet level, by using each multilocus genotype (MLG) in a patch as a separate entity, assuming that individual shoots with identical allozyme markers from a single patch belonged to the same clone. The resulting gene frequencies were analysed using BIOSYS-1 release 1.7 (Swofford \& Selander, 1981). Mean number of alleles per locus $(A)$, per cent polymorphic loci $(P)$ and allelic diversity $\left(H_{\mathrm{S}}\right.$, unbiased estimate; Nei, 1975) were used as measures of genetic variability within populations. Nei's (1973, 1975) gene diversity statistics were used to partition the total allelic diversity $\left(H_{\mathrm{T}}\right)$ into components of diversity within $\left(H_{\mathrm{S}}\right)$ and among $\left(D_{\mathrm{ST}}\right)$ populations, and to calculate diversity among populations relative to total diversity $\left(G_{\mathrm{ST}}\right)$. Nei's $(1972)$ pairwise genetic identities $(I)$ between populations were summarized into a phenogram.

The MLGs were numbered across all populations. We used several standard measures to characterize clonal diversity within populations: the proportion of distinguishable genotypes $(P D)$; Simpson's index of diversity adjusted for finite sample size $(D$; Pielou, $1969)$; and the evenness measure $(E)$ according to Fager (1972). The expected frequency was calculated for all MLGs found in more than one patch. Because the haploid gametophyte has only one set of genes, the expected frequency of a MLG can simply be calculated by multiplying the population frequencies of the genotype's alleles. Theoretically, this may lead to overestimation of the frequencies of rare alleles that would discern among different genotypes (Parks \& Werth, 1993) and underestimation of the frequencies of alleles encountered in MLGs which are likely to occur repeatedly by chance. The genet level allele frequen- cies from each of the four populations were used in these calculations, because few genotypes were encountered outside a single patch.

\section{Results}

All enzymes, with the exception of IDH, showed the expected haploid expression. IDH sometimes showed heterozygotic banding patterns probably caused by a duplication. Heterozygotes were also detected at Aco-1, Mdh-1 and Pgm-3 from extracted immature capsules, confirming the interpretations of banding patterns for these enzymes. A more complete description of banding patterns will be described elsewhere.

\section{Allozyme variation}

Out of 13 putative enzyme loci screened by electrophoresis, only two (Fba-1, Tpi-3) were monomorphic (Table 2). Using a 5 per cent criterion, 61.5 per cent of the loci surveyed were polymorphic at the species level. On average 55.7 per cent of the loci were polymorphic per population at ramet level and 53.8 per cent at genet level (Table 3 ). The mean number of alleles per locus was identical at genet and ramet levels in the populations, ranging from 1.8-2.1. Mean allelic diversity within populations $\left(H_{S}\right)$ at ramet level ranged from 0.252 in the LAT population to 0.191 in the ANE population. Genet level $H_{\mathrm{S}}$ values were similar to ramet level values, except in the LAT population, where $H_{\mathrm{S}}$ was increased to 0.332 . The total allelic diversity $\left(H_{\mathrm{T}}\right)$ based on mean allelic frequencies of polymorphic loci over all populations was $( \pm$ SE) $0.274 \pm 0.069$. Most of this variance resulted from allelic diversity within populations $\left(H_{\mathrm{s}}\right)$ rather than from differentiation among populations $\left(D_{\mathrm{ST}}\right) . G_{\mathrm{ST}}$ averaged $0.073 \pm 0.017$, indicating a high level of gene flow.

Table 1 Characteristics of the study sites

\begin{tabular}{lccl}
\hline Location & Abbreviation & Altitude $(\mathrm{m})$ & Vegetation type \\
\hline Stordalen & STO & 370 & $\begin{array}{l}\text { Subalpine Betula pubescens } \text { ssp. } \\
\text { tortuosa forest }\end{array}$ \\
$\begin{array}{l}\text { Latnjajaure } \\
\text { Långrumpsskogen }\end{array}$ & LAT & $c .1000$ & $\begin{array}{l}\text { Subarctic alpine heath } \\
\text { Lowland N. boreal zone } \\
\text { Vaccinium myrtillus }- \text { Picea abies forest } \\
\text { Lowland S. boreal zone }\end{array}$ \\
Aneboda & ANE & 100 & Vaccinium myrtillus-Picea abies forest \\
\hline
\end{tabular}

For geographical location, see Fig. 1.

(c) The Genetical Society of Great Britain, Heredity, 78, 293-301. 
Table 2 Allele frequencies at 11 polymorphic enzyme loci in four Scandinavian Hylocomium splendens populations

\begin{tabular}{|c|c|c|c|c|c|}
\hline \multirow[b]{2}{*}{ Locus } & & \multicolumn{4}{|c|}{ Population } \\
\hline & & STO & LAT & LÅN & ANE \\
\hline \multirow[t]{5}{*}{ Aat-2 } & $(N)$ & 75 & 98 & 75 & 75 \\
\hline & $a$ & - & - & 0.067 & - \\
\hline & $b$ & - & - & - & 0.013 \\
\hline & $c$ & 0.827 & 0.735 & 0.933 & 0.987 \\
\hline & $d$ & 0.173 & 0.265 & - & - \\
\hline \multirow[t]{4}{*}{ Aco-1 } & $(N)$ & 75 & 73 & 75 & 75 \\
\hline & $a$ & 0.187 & - & 0.347 & 0.467 \\
\hline & $b$ & 0.720 & 0.521 & 0.533 & 0.307 \\
\hline & $c$ & 0.093 & 0.479 & 0.122 & 0.227 \\
\hline \multirow{4}{*}{ Gpi-1 } & $(N)$ & 75 & 98 & 75 & 75 \\
\hline & $a$ & - & 0.092 & - & 0.040 \\
\hline & $b$ & 0.960 & 0.908 & 1.000 & 0.960 \\
\hline & $c$ & 0.040 & - & - & - \\
\hline \multirow[t]{5}{*}{$I d h-1$} & $(N)$ & 75 & 98 & 75 & 75 \\
\hline & $a$ & - & 0.048 & - & - \\
\hline & $b$ & 0.598 & 0.324 & 0.395 & 0.513 \\
\hline & $c$ & 0.402 & 0.629 & 0.500 & 0.487 \\
\hline & $d$ & - & - & 0.105 & - \\
\hline \multirow[t]{3}{*}{$M d h-1$} & $(N)$ & 75 & 73 & 75 & 75 \\
\hline & $a$ & 0.453 & 0.534 & 0.693 & 0.520 \\
\hline & $b$ & 0.547 & 0.466 & 0.307 & 0.480 \\
\hline \multirow[t]{3}{*}{$M d h-2$} & $(N)$ & 75 & 73 & 75 & 75 \\
\hline & $a$ & 1.000 & 1.000 & 0.933 & 1.000 \\
\hline & $b$ & - & - & 0.067 & - \\
\hline \multirow[t]{5}{*}{ Pgd-1 } & $(N)$ & 75 & 98 & 75 & 75 \\
\hline & $a$ & - & 0.224 & - & - \\
\hline & $b$ & 1.000 & 0.714 & 0.987 & 0.933 \\
\hline & $c$ & - & 0.051 & 0.013 & 0.067 \\
\hline & $d$ & - & 0.010 & - & - \\
\hline \multirow[t]{4}{*}{$P g m-1$} & $(N)$ & 75 & 98 & 75 & 75 \\
\hline & $a$ & - & - & 0.013 & 0.013 \\
\hline & $b$ & 1.000 & 0.939 & 0.920 & 0.987 \\
\hline & 0 & - & 0.061 & 0.067 & - \\
\hline \multirow[t]{5}{*}{$P g m-2$} & $(N)$ & 75 & 98 & 75 & 75 \\
\hline & $a$ & - & - & 0.013 & - \\
\hline & $b$ & 0.760 & 0.561 & 0.920 & 0.587 \\
\hline & $c$ & 0.160 & 0.357 & 0.067 & 0.200 \\
\hline & 0 & 0.080 & 0.082 & - & 0.213 \\
\hline \multirow[t]{3}{*}{$P g m-3$} & $(N)$ & 75 & 98 & 75 & 75 \\
\hline & $a$ & 0.067 & 0.041 & 0.160 & 0.013 \\
\hline & $b$ & 0.933 & 0.959 & 0.840 & 0.987 \\
\hline \multirow[t]{6}{*}{$T p i-1$} & $(N)$ & 75 & 98 & 75 & 75 \\
\hline & $a$ & - & - & 0.053 & - \\
\hline & $b$ & 0.907 & 0.990 & 0.893 & 0.987 \\
\hline & $c$ & 0.027 & - & 0.053 & 0.013 \\
\hline & $d$ & 0.067 & - & - & - \\
\hline & $e$ & - & 0.010 & - & - \\
\hline
\end{tabular}

Abbreviations for populations are given in Table 1. Plants that showed no activity at $P g m-1$ or $P g m-2$ were scored as carrying null alleles. 


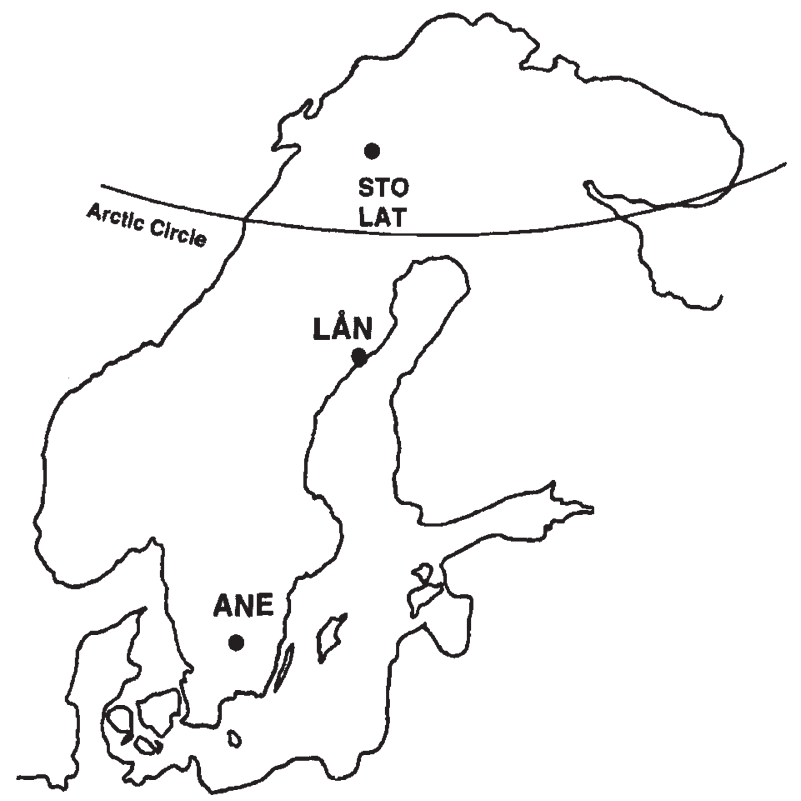

Fig. 1 Geographical location of investigated Scandinavian populations of Hylocomium splendens. Abbreviations for populations are given in Table 1.

Table 3 Allelic variation at 13 enzyme loci in four Scandinavian Hylocomium splendens populations characterized by the mean no. of alleles per locus $(A)$, percentage of polymorphic loci, 0.95 criterion $(P)$, and unbiased allelic diversity $\left(H_{\mathrm{S}}\right)$. Sample sizes $(N)$ and standard errors (within parentheses) are also given. The variability measures are calculated both at ramet and genet levels (see text).

\begin{tabular}{lcccc}
\hline Population & $N$ & $A$ & $P$ & $H_{\mathrm{S}}$ \\
\hline Ramet level & & & & \\
STO & 75 & $1.8(0.2)$ & 53.8 & $0.175(0.052)$ \\
LAT & $98 / 73^{*}$ & $2.1(0.2)$ & 61.5 & $0.252(0.064)$ \\
ANE & 75 & $1.9(0.2)$ & 38.5 & $0.191(0.069)$ \\
LÅN & 75 & $2.1(0.2)$ & 69.2 & $0.206(0.058)$ \\
Genet level & & & & \\
STO & 27 & $1.8(0.2)$ & 53.8 & $0.187(0.056)$ \\
LAT & 43 & $2.1(0.2)$ & 69.2 & $0.332(0.084)$ \\
ANE & 32 & $1.9(0.2)$ & 38.5 & $0.208(0.069)$ \\
LÅN & 22 & $2.1(0.2)$ & 53.8 & $0.210(0.058)$ \\
\hline
\end{tabular}

*The sample size is 98 for Aat-1, Gpi-1,Idh-1, Pgd-1, Pgm-1, Pgm-2, Pgm-3, Tpi-1, Tpi-2 and 73 for the rest. Two shoots died before analysis and had to be excluded from the study.

Despite wide geographical distances between the lowland populations, the genetic identities (I) between them were high (Fig. 2). The differentiation between the subarctic-alpine LAT population and

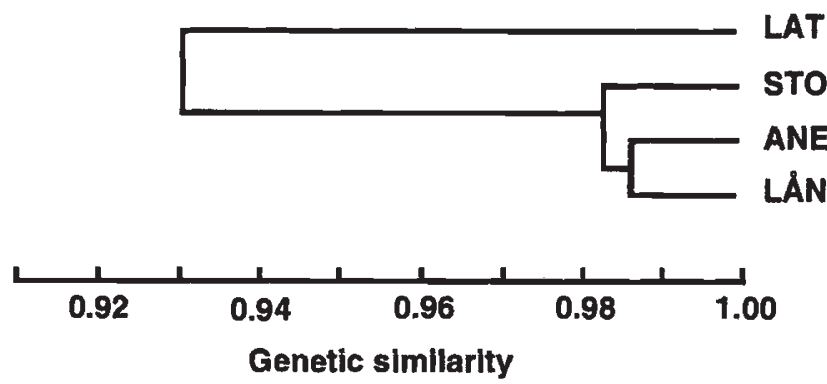

Fig. 2 Phenogram expressing overall levels of genetic similarity among four populations of Hylocomium splendens. The phenogram is based on Nei's coefficient of genetic identity $(I)$ using gene frequencies from 13 putative isozyme loci scored at the genet level (see text).

the lowland populations, including the geographically close STO population, was somewhat more distinct.

\section{Clonal diversity}

Allozyme markers allowed for accurate identification of clones. The genotypes calculated to be the most common had expected frequencies of 11.1 per cent (STO), 3.6 per cent (LAT), 9.4 per cent (LÅN) and 5.8 per cent (ANE). The highest number of MLGs was observed at LAT (Table 4). Despite this, the Simpson's index reached its lowest value in that population. The evenness index, which also had its lowest value at LAT, revealed that this may be explained by an uneven number of individuals per genotype. Altogether 79 MLGs could be detected from a total sample of 298 shoots, giving the proportion of distinguishable genotypes as 0.265 . The number of MLGs observed only once was 29 (36.7 per cent of MLGs; 10 per cent of the total no. of samples). Most of these were found in the LAT population (15), some in the ANE (10) and LAN (4) populations and none in the STO population.

Sixty-four MLGs (81 per cent) were restricted to a single patch. The number of MLGs unique to the next level in the hierarchy (subpopulation) only adds two, summing to 66 MLGs (83.5 per cent), and the third level (population) adds another five, to 71 MLGs (89.9 per cent). On the other hand, 15 MLGs were found in more than one patch (Table 5). The number of shoots carrying any of these MLGs totals 139 (46.6 per cent of total number of shoots). Almost all have the highest expected frequency, indicating that they may have arisen independently. Genotype no. 21 is exceptional in that it was recorded from one population only, LAT, where it was observed in 10 different patches. It is the only MLG which seems to be markedly more common than expected. 


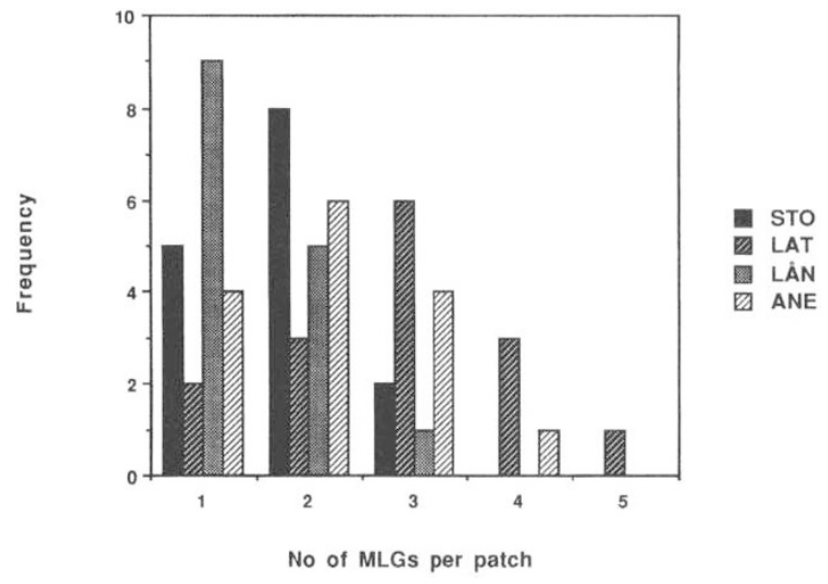

Fig. 3 The distribution of observed numbers of multilocus genotypes (MLGs) within 15 patches, sized $10 \times 10 \mathrm{~cm}$, from each of four populations of Hylocomium splendens. Five shoots have been analysed from each patch. The mean $( \pm \mathrm{SE})$ number of genotypes per patch is $2.9(0.3)$, $1.8(0.2), 1.4(0.2)$ and $2.1(0.3)$ for populations LAT, STO, LÅN and ANE, respectively.

Table 4 Clonal diversity in four Hylocomium splendens populations in Scandinavia quantified by the number of sampled ramets $(R)$, number of identified genotypes $(M L G)$, proportion of distinguishable genotypes $(P D)$, Simpson's diversity index $(D)$ corrected for infinite sample size, and evenness index $(E)$ according to Fager

\begin{tabular}{lccccc}
\hline Population & $R$ & $M L G$ & $P D$ & $D$ & $E$ \\
\hline STO & 75 & 18 & 0.240 & 0.938 & 0.986 \\
LAT & 73 & 28 & 0.384 & 0.909 & 0.722 \\
ANE & 75 & 25 & 0.333 & 0.954 & 0.979 \\
LÅN & 75 & 19 & 0.253 & 0.936 & 0.974 \\
Mean & & 22.5 & 0.302 & 0.934 & 0.915 \\
\hline
\end{tabular}

Differences among the populations were also found in the number of recorded MLGs within patches (Fig. 3). A nonparametric Kruskal-Wallis test revealed that the number of genotypes within patches was significantly higher in the LAT population than in the lowland populations $(P<0.01 ; H$ corrected for ties $=15.07$ ). Altogether 66 per cent of the patches were polymorphic, having more than one genotype. In one population, LAN, most of the patches (nine) were dominated by a single genotype and no patch had more than three genotypes. The other extreme was represented by the LAT population, in which the mean was close to three genotypes per patch and the maximal value, five genotypes, was observed in one patch. The other two populations had mean values close to two genotypes per patch.

\section{Discussion}

\section{Genetic variation}

Contrary to expectations, populations of $H$. splendens show almost as high allelic diversity within populations $\left(H_{\mathrm{S}}=0.209\right)$ as observed for populations of gymnosperms $\left(H_{\mathrm{S}}=0.271\right.$; Hamrick \& Godt, 1990), which belong to the most variable vascular plants in terms of electrophoretic variation. Hylocomium splendens is more variable than $\mathrm{N}$. European populations of Picea abies (0.168; Lagercrantz \& Ryman, 1990) under which canopy it is usually growing. The relative allelic differentiations among populations $\left(G_{\mathrm{ST}}\right)$ of $H$. splendens $(0.073)$ and Picea abies (0.051; Lagercrantz \& Ryman, 1990) are comparable to the gymnosperm average $(0.068$; Hamrick \& Godt, 1990). In contrast, other investigated bryophytes generally show a strong amongpopulation component of genetic variation. Wyatt et al. (1989) reported $G_{\mathrm{ST}}=0.171$ in mountain populations of Plagiomnium ciliare in SE USA, whereas Derda \& Wyatt (1990) found $G_{\mathrm{ST}}=0.392$ for Poly. trichum commune in E. USA and Shaw \& Rooks (1994) found $G_{\mathrm{ST}}=0.918$ for Mielichhoferia elongata from USA and N. Europe. Thus, the genetic structure of $H$. splendens is more similar to conifers than to hitherto investigated bryophytes. The highly variable and homogeneous populations of conifers are explained mainly by their long life span and an efficient gene flow by means of wind-dispersed pollen and seeds (Hamrick \& Godt, 1990). Apparently, the perennial stayer life strategy in combination with wind-dispersed spores play a similar role in $H$. splendens.

\section{Clonal diversity}

The mean value of the Simpson's index for populations of $H$. splendens $(0.934)$ is high compared to other clonal plants (cf. review by Widén et al., 1994), contradicting the view that $H$. splendens is exclusively vegetatively reproducing. In the moss Climacium americanum 30 per cent of the patches were polymorphic (Meagher \& Shaw, 1989) as compared to 66 per cent for $H$. splendens. Given the short fertilization distance of bryophytes (Wyatt, 1982) multiclonal patches are essential for successful sexual reproduction.

Several factors could account for the localized distribution of genotypes, e.g. boulders, big trees, etc. could act as physical barriers for vegetative dispersal. Thus the observed re-establishment (Økland, 1995) would take place mostly over short distances. 
Table 5 Multilocus genotypes encountered multiple times in four populations of Hylocomium splendens: expected number of observations (Exp. pop.) within a population vs. recorded number of observations (Rec. pop.) within a population, and within different patches (Rec. patch) within a population. ID, multilocus genotype identification; $P$, expected frequency of the genotype within the population; Rank, rank order of the expected frequency of a genotype when the most probable genotype is ranked as number one; all possible combinations of alleles are ranked

\begin{tabular}{lrccrrr}
\hline Population & ID & $P$ & $\begin{array}{l}\text { Exp. } \\
\text { pop. }\end{array}$ & $\begin{array}{l}\text { Rec. } \\
\text { pop. }\end{array}$ & $\begin{array}{r}\text { Rec. } \\
\text { patch }\end{array}$ & Rank \\
\hline STO & 1 & 0.014 & 1.1 & 9 & 3 & 7 \\
& 2 & 0.023 & 1.8 & 1 & 1 & 6 \\
& 3 & 0.032 & 2.4 & 2 & 2 & 5 \\
& 4 & 0.103 & 7.7 & 9 & 3 & 2 \\
& 6 & 0.111 & 8.3 & 8 & 4 & 1 \\
LAT & 16 & 0.069 & 5.1 & 4 & 2 & 4 \\
& 17 & 0.074 & 5.6 & 3 & 1 & 3 \\
& 16 & 0.036 & 2.6 & 2 & 1 & 1 \\
& 17 & 0.029 & 2.1 & 8 & 4 & 3 \\
& 19 & 0.032 & 2.3 & 1 & 1 & 2 \\
ANE & 21 & 0.024 & 1.8 & 19 & 10 & 4 \\
& 25 & 0.025 & 1.8 & 5 & 2 & 4 \\
& 32 & 0.000 & 0.01 & 4 & 2 & $>10$ \\
& 35 & 0.002 & 0.12 & 1 & 1 & $>10$ \\
& 2 & 0.051 & 3.8 & 8 & 2 & 3 \\
& 4 & 0.034 & 2.5 & 5 & 1 & 6 \\
& 16 & 0.036 & 2.7 & 7 & 3 & 5 \\
& 17 & 0.032 & 2.4 & 3 & 1 & 7 \\
& 35 & 0.006 & 0.42 & 4 & 1 & $>10$ \\
LÅN & 48 & 0.048 & 3.5 & 2 & 2 & 4 \\
& 49 & 0.058 & 4.3 & 3 & 2 & 1 \\
& 61 & 0.020 & 1.5 & 4 & 2 & 10 \\
& 3 & 0.053 & 4.0 & 3 & 1 & 4 \\
& 4 & 0.059 & 4.4 & 11 & 3 & 3 \\
& 16 & 0.094 & 7.0 & 9 & 2 & 1 \\
& 19 & 0.028 & 2.1 & 4 & 1 & 5 \\
& 49 & 0.084 & 6.3 & 1 & 1 & 2 \\
\hline
\end{tabular}

\section{Alpine vs. lowland populations}

The population structures of the three lowland populations are similar whereas the alpine LAT population is more deviant. Possibly the difference in population density, the alpine populations typically being 3-4 times denser than the lowland populations (Cronberg, unpublished), may be part of the explanation. The widespread genotype no. 21 at LAT indicates a larger extent of vegetative dispersal by fragmentation, perhaps caused by the harsher climatic conditions with frost action and strong winds.

The material investigated here is not sufficient to address specifically the question of the taxonomic position of $H$. alaskanum. However, larger genetic distances between the alpine population vs. the lowland populations may indicate different evolutionary histories. Because the difference is small, and morphologically intermediate plants have frequently been reported (Persson \& Viereck, 1983), recognition at the specific level seems unjustified. More work is currently being undertaken to test this.

The surprisingly high levels of variation found in the arctic-alpine LAT population has a parallel in a study of Plagiomnium ciliare (Wyatt et al., 1989). Populations of this species were shown to be more variable in primary forests of the Appalachian Mountains as compared to lowland populations of the Piedmont (Wyatt et al., 1989). Wyatt et al. proposed that the genetic diversity of lowland populations was reduced during a period of deforestation. 
This is unlikely in the present case because the lowland populations were chosen to be comparatively undisturbed.

In contrast, alpine populations of both Sphagnum capillifolium and $S$. rubellum are less variable in terms of allelic diversity $\left(H_{\mathrm{S}}\right)$ compared to lowland populations (Cronberg, in prep). Montagnes et al. (1993) found a similar pattern in N. American populations of the moss Meesia triquetra, with boreal sites having high within-site diversity, subarctic sites having high between-site diversity, and high arctic sites being consistently of low variability. It is likely that the harsh climate at arctic and alpine sites restricts the opportunities for sporophyte production in these species. If sexual reproduction is rare at high elevations in $H$. splendens, spores may arrive from fertile populations at lower elevations. Furthermore, theoretical models predict that given the potentially long life of clones, the incidence of successful sexual reproduction need not be high to maintain clonal diversity in the populations (Soane \& Watkinson, 1979). Accordingly, much variation $\left(H_{\mathrm{S}}=0.167\right)$ and a high clonal diversity was encountered in an electrophoretic survey of three populations of the clonal sedge Carex bigelowii from Icelandic lava fields, despite documented lack of recruitment (Jonsson et al., 1996). The examples $C$. bigelowii and $H$. splendens show that arctic populations of clonal species with low apparent sexual reproduction need not necessarily be genetically depleted.

\section{Genetic variability and adaptation}

Wyatt et al. (1989) proposed that the unexpectedly high levels of genetic variation encountered in several bryophytes could be explained by genetic adaptation to microhabitats. In the dominant haploid generation of bryophytes a close correlation between the habitat and genotype is possible, because, in principle, all genes are expressed. Eriksson (1993) stressed that the prerequisites for evolving locally adapted genotypes are best fulfilled for clonal plants in which recruitment occurs within patches of established genets, because successive generations of genets experience similar environmental conditions at particular sites. The abundant genetic variation, occurrence of multiclonal populations and localized clonal structure of $H$. splendens, may be a consequence of genetic adaptation to microhabitats.

At present, no evidence exists in support of this theory. The wide ecological amplitude of $H$. splendens has been attributed to a flexible phenotypic response rather than genetic adaptation. Kallio \& Saarnio (1986) could show that the differences in photosynthetic assimilation rate of collections of $H$. splendens, Pleurozium schreberi and Racomitrium lanuginosum representing three climate zones largely disappeared after transplantation. Investigations of microsite conditions and spatial separation within the forest floor moss communities, to which $H$. splendens belongs, have failed to find differences in the fundamental niches of coexisting species (Frego \& Carleton, 1995a,b), indicating that niche differentiation of different clones within species is unlikely. Recent demographic studies ( $\varnothing$ kland, 1994, 1995) show a fairly fast turnover of shoots of $H$. splendens. It can therefore be questioned whether exclusion of genotypes by intraspecific competition takes place at all.

\section{Acknowledgements}

The authors wish to thank Laura Bergwall for technical assistance and Rune $H$. Økland, Oslo, for valuable comments on the manuscript. Field work at Latnjajaure was supported by a grant from the Swedish Natural Science Research Council (NFR) to U.M. This study was completed during a postdoctoral stay at the Botanical Laboratory, Copenhagen University, sponsored by an EU grant, ERBCHBICT481809 to N.C.

\section{References}

Callaghan, T. V., COllins, N. J. AND Callaghan, C. H. 1978. Photosynthesis, growth and reproduction of Hylocomium splendens and Polytrichum commune in Swedish Lapland. Oikos, 31, 73-88.

DERDA, G. S. AND WYATT, R. 1990. Genetic variation in the common hair-cap moss, Polytrichum commune. Syst. Bot., 15, 592-605.

DURING, H. J. 1992. Ecological classification of bryophytes and lichens. In: Bates, J. W. and Farmer, A. M. (eds) Bryophytes and Lichens in a Changing Environment, pp. 1-31. Clarendon Press, Oxford.

Ellstrand, N. C. AND Roose, M. L. 1987. Patterns of genotypic diversity in clonal plant species. Am. J. Bot., 74, $121-131$.

ERIKSSON, O. 1993. Dynamics of genets in clonal plants. Trends Ecol. Evol., 8, 313-316.

FAGER, E. W. 1972. Diversity: a sampling study. Am. Nat., 106, 293-310.

FREGo, K. A. AND CARleton, T. J. 1995a. Microsite conditions and spatial pattern in a bryophyte community under mature black spruce. Can. J. Bot., 73, 544-551.

FREGo, K. A. AND CARleton, T. J. 1995b. Microsite tolerance of four bryophytes in a mature black spruce stand: reciprocal transplants. Bryologist, 98, 425-458. 
HAMRICK, J. L. AND GODT, M. J. 1990. Allozyme diversity in plant species. In: Brown, A. H. D., Clegg, M. T., Kahler, A. L. and Weir, B. S. (eds) Plant Population Genetics, Breeding and Genetic Resources, pp. 3-63. Sinauer Associates, Sunderland, MA.

hermANUTZ, L. A., INNES, D. J. AND WEIS, I. M. 1989. Clonal structure of arctic dwarf birch (Betula glandulosa) at its northern limit. Am. J. Bot., 76, 755-761.

Jonsson, B. G. 1993a. The bryophyte diaspore bank and its role after small-scale disturbance in a boreal forest. $J$. Veg. Sci., 4, 819-826.

Jonsson, B. G. 1993b. Treefall Disturbance, Succession, and Diversity in Boreal Forest Floor Vegetation. Ph.D. Thesis, University of Umeå.

KALliO, P. AND SAARNiO, E. 1986. The effect on mosses of transplantation to different latitudes. J. Bryol., 14, 159-178.

JONSSON, B. O., JÓNSDÓTTIR, I. S. AND CRONBERG, N. 1996. Clonal diversity and allozyme variation in populations of the arctic sedge Carex bigelowii (Cyperaceae). J. Ecol., 84, 449-459.

LAGERCRANTZ, U. AND RYMAN, N. 1990. Genetic structure of Norway spruce (Piecea abies): concordance of morphological and allozymic variation. Evolution, 44, $38-53$.

LONGTON, R. E. AND SCHUSTER, R. M. 1983. Reproductive ecology. In: Schuster, R. M. (ed.) New Manual of Bryology, pp. 386-462. Hattori Bot. Lab, Nichinan.

MÅRTENSSON, O. 1956. Bryophytes of the Torneträsk area, Northern Swedish Lapland. II Musci. K. Sv. Vetenskapsakad. Avh. naturskydd., 14, 1-321.

MEAGHER, T. R. AND SHAW, J. 1989. Clonal structure in the moss, Climacium americanum Brid. Heredity, 64, 233-238.

MISHLER, B. D. 1988. Reproductive ecology of bryophytes. In: Lovett Doust, J. and Lovett Doust, L. (eds) Plant Reproductive Biology. Patterns and Strategies, pp. 285-306. Oxford University Press, Oxford.

MOLAU, U. 1993. Relationships between flowering phenology and life history strategies in tundra plants. Arctic Alpine Res., 25, 391-402.

MONTAGNES, R. J. S., BAYER, R. J. AND VITT, D. H. 1993. Isozyme variation in the moss Meesia triquetra (Meesiaceae). J. Hattori Bot. Lab., 74, 155-170.

MYRMAEL, A. 1993. Regeneration studies of five spruce, Picea abies, forest bryophytes. Lindbergia, 18, 7-18.

NEl, M. 1972. Genetic distance between populations. Am. Nat., 106, 238-292.

NEl, M. 1973. Analysis of gene diversity in subdivided populations. Proc. Natl. Acad. Sci., U.S.A., 70, $3321-3323$.

NEl, M. 1975. Molecular Population Genetics and Evolution. North Holland, Amsterdam and New York.

ØKLAND, R. H. 1994. Bryophyte and lichen persistence patterns in a Norwegian boreal coniferous forest. Lindbergia, 19, 50-62.

$\varnothing K L A N D$, R. H. 1995. Population biology of the clonal moss Hylocomium splendens in Norwegian boreal spruce forests. I. Demography. J. Ecol., 83, 697-712.

PARKS, J. C. AND WERTH, C. R. 1993. A study of spatial features of clones in a population of bracken fern, Pteridium aquilinum (Dennstaedtiaceae). Am. J. Bot., 80, 537-544.

PERSSON, H. AND VIERECK, L. A. 1983. Collections and discussions of some bryophytes from Alaska. Lindbergia, 9, 5-20.

PIElou, E. C. 1969. An Introduction to Mathematical Ecology. Wiley-Interscience, New York.

SCHOFIED, w. B. 1985. Introduction to Bryology. Macmillan, New York.

SHAW, A. J. AND ROOKS, P. E. 1994. Systematics of Mielichhoferia (Bryaceae: Musci) I. Morphological and genetic analyse of $M$. elongata and $M$. mielichhoferiana. Bryologist, 97, 1-12.

SOANE, 1. D. AND WATKINSON, A. R. 1979. Clonal variation in populations of Ranunculus repens. New Phytol., 82, 557-573.

SOLTIS, D. E., HAUFLER, C. H., DARROW, D. C. AND GASTONY, G. J. 1983. Starch gel electrophoresis of ferns: A compilation of grinding buffers, gel and electrode buffers and staining schedules. Am. Fern J., 73, 9-27.

SONESSON, M., GEHRKE, C. AND TJUS, M. 1992. $\mathrm{CO}_{2}$ environment, microclimate and photosynthetic characteristics of the moss Hylocomium splendens in a subarctic habitat. Oecologia, 92, 23-28.

STONEBURNER, A., WYATT, R. AND ODRZYKOSKI, I. J. 1991. Applications of enzyme electrophoresis to bryophyte systematics and population biology. Adv. Bryol., 4, 1-27.

swofford, D. L. AND SElAnder, R. B. 1981. BIOSYs-1. A computer program for the analysis of allelic variation in population genetics and biochemical systematics. Release 1.7. University of Illinois, Urbana, IL.

TAMM, C. O. 1953. Growth, yield and nutrition in carpets of a forest moss (Hylocomium splendens). Meddn. St. SkogforskInstit., 43, 1-140.

WENDEL, J. F. AND WEEDEN, N. F, 1989. Visualization and interpretation of plant isozymes. In: Soltis, D. E. and Soltis, P. S. (eds) Isozymes in Plant Biology, pp. 5-45. Dioscorides Press, Portland, OR.

WIDÉN, B., CRONBERG, N. AND WIDÉN, M. 1994. Genotypic diversity, molecular markers and spatial distribution in clonal plants, a literature survey. Folia Geobot. Phytotax., Praha, 29, 245-263.

WYATT, R. 1982. Population ecology of bryphytes. J. Hattori Bot. Lab., 52, 170-198.

WYATT, R., ODRZYKOSK1, I. J. AND STONEBURNER, A. 1989. High levels of genetic variability in the haploid moss Plagiomnium ciliare. Evolution, 43, 1085-1096. 